This article was downloaded by: [Bruno Vandecasteele]

On: 22 May 2015, At: 12:03

Publisher: Routledge

Informa Ltd Registered in England and Wales Registered Number: 1072954 Registered

office: Mortimer House, 37-41 Mortimer Street, London W1T 3J H, UK

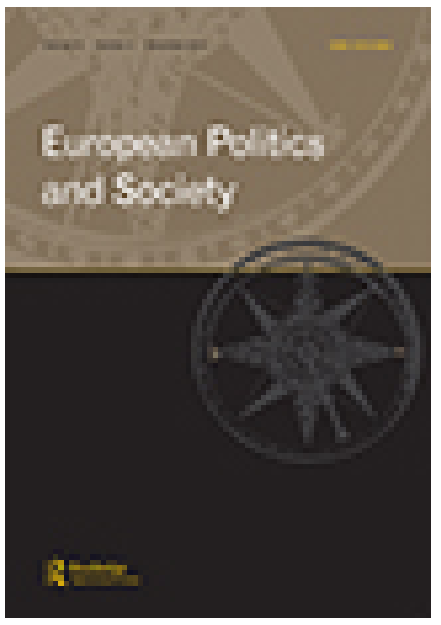

\title{
European Politics and Society
}

Publication details, including instructions for authors and subscription information:

http:// www.tandfonline.com/loi/ rpep21

\section{A Fuzzy-Set Qualitative Comparative Analysis of the Hungarian, Polish and Lithuanian Presidencies and European Union Eastern Partnership Policies}

Bruno Vandecasteele ${ }^{a}$, Fabienne Bossuyt ${ }^{a} \&$ J an Orbie ${ }^{a}$

${ }^{a}$ Centre for EU Studies, University of Ghent, Belgium Published online: 22 May 2015.

\section{CrossMark}

Click for updates

To cite this article: Bruno Vandecasteele, Fabienne Bossuyt \& J an Orbie (2015): A FuzzySet Qualitative Comparative Analysis of the Hungarian, Polish and Lithuanian Presidencies and European Union Eastern Partnership Policies, European Politics and Society, DOI: $10.1080 / 23745118.2015 .1039248$

To link to this article: http:// dx. doi.org/ 10.1080/23745118.2015.1039248

\section{PLEASE SCROLL DOWN FOR ARTICLE}

Taylor \& Francis makes every effort to ensure the accuracy of all the information (the "Content") contained in the publications on our platform. However, Taylor \& Francis, our agents, and our licensors make no representations or warranties whatsoever as to the accuracy, completeness, or suitability for any purpose of the Content. Any opinions and views expressed in this publication are the opinions and views of the authors, and are not the views of or endorsed by Taylor \& Francis. The accuracy of the Content should not be relied upon and should be independently verified with primary sources of information. Taylor and Francis shall not be liable for any losses, actions, claims, proceedings, demands, costs, expenses, damages, and other liabilities whatsoever or howsoever caused arising directly or indirectly in connection with, in relation to or arising out of the use of the Content.

This article may be used for research, teaching, and private study purposes. Any substantial or systematic reproduction, redistribution, reselling, loan, sub-licensing, systematic supply, or distribution in any form to anyone is expressly forbidden. Terms \& 
Conditions of access and use can be found at http://www.tandfonline.com/page/termsand-conditions 


\title{
A Fuzzy-Set Qualitative Comparative Analysis of the Hungarian, Polish and Lithuanian Presidencies and European Union Eastern Partnership Policies
}

\author{
BRUNO VANDECASTEELE, FABIENNE BOSSUYT \& JAN ORBIE \\ Centre for EU Studies, University of Ghent, Belgium
}

\begin{abstract}
This article analyses and compares the influence of the Hungarian, Polish and Lithuanian Presidencies of the Council of the European Union (taking place between 2011 and 2013) on the Union's policies towards the countries of the Eastern Partnership - Belarus, Ukraine, Moldova, Georgia, Armenia and Azerbaijan. The influence of the Presidencies is compared through qualitative comparative analysis (QCA), which aims to identify necessary and sufficient conditions for influence to occur. The results show that there is only one necessary condition for the Presidency to exert influence, that is, the issue should be highly salient to the incumbent Member State. The absence of any other condition for influence does as such not hamper Presidency influence. Moreover, the analysis reveals three sufficient combinations of conditions for Presidency influence, in which the individual conditions play different roles. The application of QCA to Presidency influence leads to novel insights and stimulates conceptual clarity on the level of and the conditions for influence.
\end{abstract}

KeY WORDS: Hungary, Poland, Lithuania, Presidency of the Council of the EU, influence, qualitative comparative analysis

\section{Introduction}

The question whether the Member States of the European Union (EU) can exert additional influence on EU decision-making when holding the rotating Council Presidency (hereinafter: Presidency) has inspired a lively academic debate in the past decades. While some have argued that the Member States do not use their Presidency position to increase their influence (Dewost, 1984; Ludlow, 1993; Hayes-Renshaw \& Wallace, 2006; Vida, 2010; Culley et al., 2011), others have shown that Member States holding the Presidency do exert additional influence during their term at the helm (Arter, 2000; Bjurulf, 2001; Tallberg, 2004; Schalk et al., 2007; Warntjen, 2007; Thomson, 2008; Bunse, 2009). Several instruments for exerting influence have been identified, such as issue decoupling

Correspondence Address: Bruno Vandecasteele, Centre for EU Studies, University of Ghent, Universiteitstraat 8, 9000 Ghent, Belgium. Email: bruno.vandecasteele@ugent.be 
(subtraction) or coupling (package deals), compromise proposals, additional meetings (Warntjen, 2013b) and different forms of agenda shaping (Tallberg, 2003).

The evidence on Presidency influence is increasingly well documented and theoretically informed, and a large number of conditions affecting Presidency influence have been identified (see infra). However, it is still unclear if and how these conditions can jointly strengthen or limit Presidency influence. This is the underlying research puzzle of this article: it addresses the question which conditions are necessary and/or sufficient for a Presidency to exert influence through a study of the Hungarian, Polish (both 2011) and Lithuanian (2013) Presidencies and their influence on the EU's Eastern Partnership ${ }^{1}$ $(\mathrm{EaP})$ policies. The main rationale behind this research question is that the three Presidencies exerted influence to varying degrees in different policy areas; the aim is to explain which conditions contributed to influence in terms of necessity and sufficiency.

The empirical focus of the article is based on three considerations. The first two are initial scope conditions: the article focuses on (i) external policies in which the Presidency can play a role and on (ii) a geographical area in which the Presidencies are to a certain extent interested to play a role. Indeed, the EaP policies first of all constitute an area of EU external policies in which the Presidency is potentially influential: contrary to 'classic' foreign policy, in which the EU's High Representative and the European External Action Service (EEAS) play an important role, EaP policies cover a broad range of external policy areas where the Presidency has key responsibilities at different stages of policymaking, that is, in certain working parties, in Coreper and during ministerial meetings. Second, Hungary, Poland and Lithuania are interested in further integration between the EU and (some of) its Eastern neighbouring countries. Earlier research suggests that Presidency periods are opportunities for Member States to promote their views on external policies and to steer political attention in the EU to specific regions (for Central and Eastern EU members, see, e.g. Tulmets, 2011). It can thus be expected that these three Presidencies will at least try to influence some aspects of EaP policies. The third consideration for case selection is that the influence of the Presidency on external policies has received rather little attention in the academic literature compared to other policy domains, and existing research on this topic (Arter, 2000; Tallberg, 2006b; Bunse, 2009; Dijkstra, 2011) discusses cases pre-dating 2009, that is, before the Treaty of Lisbon entered into force. Since this treaty changed the role of the Presidency (Charléty \& Mangenot, 2011; Craig, 2011; Vanhoonacker et al., 2011; Warntjen, 2013a), especially in external policies, research on Presidency influence in this renewed institutional setting contributes to understanding current decision-making processes in the EU.

Presidency influence is explored through fuzzy-set qualitative comparative analysis (fsQCA), which allows us to make systematic analyses of sufficient and necessary conditions for influence. Qualitative comparative analysis (QCA) is a set-theoretic method that works with membership scores of cases in sets (i.e. 'presence' or 'absence' of a condition or an outcome), perceives relations between social phenomena as set relations, and interprets these set relations in terms of sufficiency and necessity (for recent overviews on QCA, see Rihoux \& Ragin, 2009; Schneider \& Wagemann, 2012). As explained in the appendix to this article, 'influence' is defined here as intentionally changing a policy from what it would have been in the absence of an action. The degree of political influence (PI) of an actor is expressed as a function of the actor's goal achievement, the extent to which this goal achievement can be ascribed to the actor and the political relevance of the output. 
The empirical data used in this article are drawn from extensive desk- and field research, including analyses of official documents from the EU institutions and the Member States, secondary sources such as academic and news articles, and 81 in-depth interviews with officials of EU Member States and institutions between January 2012 and August 2014. Due to space constraints, these data are not elaborated in the main body of the article; detailed descriptions of the data on influence of the Presidencies are available in three online country files, and information on the operationalization of concepts can be found in the appendix to this article.

With this article, we aim to make an empirical and a methodological contribution to the literature on Presidency influence. Empirically, the article summarizes and analyses a large amount of data on the role and influence of three Presidencies in shaping the EU's relations with its Eastern neighbours (see Supplemental data 1-3, which is available from the article's Taylor \& Francis Online page at http://dx.doi.org/10.1080/23745118.2015. 1039248). Methodologically, it is the first systematic comparison of Presidency influence with QCA, a method that - in distinguishing between necessary and sufficient conditions enhances debates on the conditions for (Presidency) influence.

The remainder of the article is structured as follows: the next section gives an overview of the conditions for influence. Subsequently, we briefly discuss the benefits and challenges of applying QCA in this article, and then provide a summary of the policy areas in which - and to what extent - the Hungarian, Polish and Lithuanian Presidencies did and did not exert influence. This is followed by a summary of the empirical data for this article, including information on the extent to which the conditions for influence apply to the respective Presidencies. The last part of the article discusses and interprets the results of the comparison with QCA. The conclusion summarizes these results and makes a few suggestions of topics for future research.

\section{Conditions for Influence}

A large number of conditions for Presidency influence have been identified in the literature (for an overview, see, e.g. Vandecasteele \& Bossuyt, 2014), however, without clear indications on possible conjunctural causality. With this article, we aim to provide a systematic analysis of the necessity and sufficiency of (combinations of) these conditions with the Hungarian, Polish and Lithuanian Presidencies as an empirical basis. This section summarizes the conditions for influence, including the abbreviations that will be used in the tables for fsQCA. Detailed information on operationalization of these conditions is available in the appendix.

The conditions for influence can be divided into three groups (see also Van Hecke \& Bursens, 2011, p. 25): country-specific conditions, conditions related to policy areas or specific issues, and conditions related to the external context.

Among the country-specific conditions, adequate preparation ('prep') is expected to contribute to Presidency influence (Arter, 2000; Bunse, 2009). It involves efficient planning, staff training and careful formulation of priorities. Adequate preparation ensures that the Presidency is ready for expected and even unexpected developments in the EU that the procedures and informal rules are applied routinely, and that dossiers can be identified where progress (or delay if so wished) are possible. The planning should consider the political calendar of the EU and of world politics, such as elections in key Member States, important summits and multilateral events. 
Second, the division of labour between the permanent representation (permrep) and the national capital is discussed in the literature as affecting Presidency influence. Bunse (2009) argues that Presidencies allowing large autonomy to the permrep are more influential than strictly capital-based ones. The argument is that Brussels-based officials know best where the sensitivities lie and which compromises are feasible. The degree of 'Brusselsbased Presidency' (in fsQCA: 'bru') can differ between policy areas, depending on issues such as the internal organization of administrations, the importance of the topic or the availability of expertise.

A third country-specific condition is the reputation ('reput') of the incumbent Member State (Metcalfe, 1998; Bjurulf, 2001; Baun, 2009; Bunse, 2009). Incumbent countries with a good reputation enjoy more trust among the other Member States and the EU institutions, which makes influence on decisions more likely. For this article, 'good reputation' is conceptualized along three dimensions (on reputation, see Quaglia \& Moxon-Browne, 2006; Bunse, 2009; Jakobsen, 2009): (i) the incumbent country is considered to give the 'right example' in domestic policies, (ii) the political leadership of a country displays a positive attitude towards European integration and (iii) the Presidency invests in soft knowledge of chairpersons. Giving the 'right example' at home means that domestic policies correspond to what is generally accepted by the other Member States and the EU institutions. A positive attitude towards European integration refers to the absence of hostility towards (one or several aspects of) European integration (Crespy \& Verschueren, 2009). Such hostility would lessen trust of the other Member States and EU institutions (Leconte, 2012), thus reducing the Presidency's ability to exert influence. The third dimension, soft knowledge, ${ }^{2}$ includes negotiation, managerial and organizational skills, experience in multicultural environments, rhetoric, teamwork, stress control, transparent planning, clear communication, effective use of the available rooms and networking (see, e.g. Bjurulf, 2001; Bunse, 2009; Kajnč, 2009; Vanhoonacker et al., 2010; Karoliewski \& Sus, 2011).

Fourth, the role of size of the incumbent country is to be tested: the literature is as yet inconclusive on how size contributes to influence. Several authors (Bjurulf, 2001; Bengtsson, 2002; Kajnč \& Svetličič, 2010) argue that a Member State's size does not affect its ability to manage practical issues. However, large countries (in fsQCA: 'large') are generally supposed to be more influential in the Council than smaller ones (Tallberg, 2008) and, in external policies, large States function more autonomously than small States and thus have more room for manoeuvre (Dijkstra, 2011). However, others (Baillie, 1998; Thorhallsson \& Wivel, 2006; Björkdahl, 2008) point out that small States can use the Presidency to increase their influence on decision-making in the EU, since they are usually not expected to (be able to) push their interests in the same way as large States do (Vanhoonacker et al., 2010). In any case, it is unclear whether small States have more or less influence than large States during their Presidency (Warntjen, 2007).

A fifth country-specific condition to be considered is the effect of a stable domestic political and administrative context ('stab.dom'): effective intra- and inter-departmental coordination (Baun, 2009; Bunse, 2009, p. 64) and a stable Government with a strong mandate (Copsey \& Pomorska, 2010) can be expected to increase the influence of a Member State, especially during a Presidency period. It is argued that, in a stable domestic situation, the incumbent country can concentrate on the Presidency's agenda and goals and does not have to direct resources to internal coordination.

In addition to these country-specific conditions, two conditions related to specific policy areas will be considered. ${ }^{3}$ First, salience of a policy area to the Presidency ('sal.pres') 
refers to the importance of the area and the willingness of the incumbent country to spend resources (time, staff, funds) in order to achieve its goals in this area. High salience generally motivates the development and mobilization of hard knowledge among a country's civil servants and politicians, which results in a higher potential for influence. In turn, low salience entails little hard knowledge (Schalk et al., 2007; Warntjen, 2007). This condition has been used in bargaining models for studying legislative decision-making in the EU (see also Thomson \& Stokman, 2006). In our view, the effect of this condition (i.e. more attention for the topic, more hard knowledge) can be equally important in decision-making on external policies. 'Salience' as a condition for influence should not be confused with 'political relevance' as an indicator for PI (see Appendix). 'Salience' refers to the importance of an issue for an actor or the intensity of its preferences regarding a policy area. The salience of an issue to the Presidency is assessed from two types of sources: the Presidency programme, on the one hand, and in-depth interviews and secondary sources, on the other. The latter sources provide insights into the salience of unexpected events and of issues that were not included or under/overemphasized in the Presidency programme. ${ }^{4}$ In turn, 'political importance' is a measure for the relevance of an issue for the relations between the $\mathrm{EU}$ and $\mathrm{EaP}$ countries, including the political importance of the issue (i.e. its political and symbolic value) for EU-EaP relations, as well as the novelty and tangibility of the policy development. The sources for assessing political relevance are not drawn from Presidency-related data. Instead, the degree of political relevance is established through an assessment of the researcher-based official documents and secondary literature.

Second, a favourable distribution of preferences and salience among other actors (Member States, institutions) (in fsQCA: 'fav.pref/sal.oth') affects the extent to which the Presidency can influence EU policies. The effects of heterogeneity of preferences and salience to the other actors are two different things that partially interact with each other, and can therefore be formulated as one condition. The lower the salience of a policy area to the other actors, the more room for manoeuvre they may give to the chair and vice versa (Bjurulf, 2001; Bunse, 2009). At the same time, some authors (Fernández Pasarín, 2009; Bursens \& Van Hecke, 2011) argue that the incumbent country can realize its national preferences only if there is a certain degree of homogeneity between the agendas of the Presidency and other actors in the EU. If there is too large a 'mismatch' between agendas, it is less likely that the Presidency will achieve its goals. This condition will not be considered separately in the online country files: the distribution of EaP-related preferences and salience among the actors in the EU was generally stable in 2011-13. There was a consensus that the region 'matters', but points of view diverged on the intensity, scope, underlying principles and finality of EU-EaP cooperation. As explained in the next section, we have defined eight policy areas on which the Presidencies did or did not exert PI. In some policy areas, the distribution of preferences and salience among other actors is considered 'rather favourable' $(0.67)$, while in other areas, this is 'rather unfavourable' (0.33) (Interview 3, 10, 11, 12; Vaïsse et al., 2013). The former group includes cooperation on education and research, youth, trade and economy, and transport. The latter group consists of politically sensitive issues, topics that directly affect national interests and policies involving considerable funds: bilateral political relations, defence, energy, justice and home affairs (JHA, especially mobility of persons and human rights) and the multilateral institutional framework for cooperation.

Finally, two context-related conditions broadly shape the environment in which the Presidency operates. The external political context (Baun, 2009), or leadership environment 
(Bunse, 2009), is constituted by the political climate in the EU with regard to the topics of interest to the Presidency (e.g. the context of relations with candidate countries is different from that for neighbouring countries of the EU), domestic politics in EU countries or global events (e.g. election campaigns in key Member States or on-going multilateral negotiations that could distract attention for the topics the Presidency wants to emphasize), and unexpected events or crises (e.g. natural or man-made disasters that can jeopardize the Presidency programme) (see, e.g. Vos \& Bailleul, 2002; Langdal \& von Sydow, 2009). A 'favourable external political context' is abbreviated as 'fav.ext'.

Also, the European economic context (see, e.g. Baun, 2009) may affect the Presidency's influence, especially if the incumbent country has high ambitions for new or enhanced policies. Economic decline can lead to less support within the EU for reforms or new commitments, while in periods of economic prosperity, EU Member States are more open to new initiatives (Pintelon \& Van Lancker, 2011). At the same time, periods of economic crisis, if skilfully handled, can provide a window of opportunity to the Presidency to initiate reforms and steer policies in line with its preferences.

\section{Applying QCA for Analysing Influence: Benefits and Challenges}

In this article, we apply the fuzzy-set variant of QCA and its homonymous software package fsQCA, which allows us to analyse differences in kind and differences in degree: membership scores of the conditions and the outcome range between 0 and 1. We manually assign the membership scores to conditions and outcomes, based on theoretical arguments. Full details on operationalization of influence and the conditions for influence are provided in the appendix.

In systematically comparing the influence of different Presidencies, QCA provides three important benefits (see, e.g. Berg-Schlosser et al., 2009). First, because QCA is able to deal with high causal complexity, it has the potential to identify combinations of conditions that jointly produce an outcome. Second, QCA is an ideal comparative method in a small- to medium- $N$ research design. Third, the assessment of necessity and sufficiency yields more fine-tuned results than most other comparative methods, and allows us to exclude causal conditions that are unnecessary or that are not part of sufficient causal paths.

QCA also poses two challenges. First, the use of numbers and scores to describe set membership may create a false impression of precision, for example, that 0.60 is exactly twice as much as 0.30 . This is not how the numbers should be interpreted: the scores represent verbal assessments on an ordinal, not on an interval scale. 0.30 means 'rather no member' of a set (below the threshold value for membership of 0.50 ), whereas 0.60 is 'rather a member' (above 0.50). These numbers translate verbal assessments and should also be interpreted as such.

The second challenge is related to the number of cases for each Presidency. It would be inadequate to treat all EaP-related outputs - that is, all EaP-related policy developments, including issues that were placed on the agenda, decisions that were taken or the absence of such anticipated developments - as separate cases: the online country files show that there were more EaP-related outputs to be considered for the Polish and Lithuanian Presidencies than for the Hungarian Presidency. Although Hungary exerted influence on less outputs than the other two Presidencies, it was influential in a relatively higher number of outputs when compared to the total number of EaP-related events during its Presidency. Due to the formula used for calculating sufficiency with QCA, this would lead to a 
disproportionate importance of the results concerning Hungary, even though Hungary was the least interested in the EaP region and it exerted the least influence among the three Presidencies in this study. For this reason, the cases for comparison are established in two steps: first, the degree of Presidency influence is calculated for each output per Presidency according to the principles outlined infra. Second, the outputs are grouped for each Presidency into equal numbers of "policy areas ${ }^{5}$ on which the EU cooperates with the EaP countries. These policy areas will serve as the 'cases' for analysis: bilateral political relations, defence, education/research/youth, energy, JHA (including customs cooperation), multilateral political and institutional framework (including formats for multilateral cooperation and EaP Summits), trade/economic relations and transport cooperation.

The membership score for influence in a policy area is represented by the maximum score of the outputs in this policy area. If, for example, the Presidency was influential on two outputs (e.g. with scores of 0.56 and 0.67 ) in the area of transport, and not influential on three other outputs in this area (say, with scores of $0.00,0.33$ and 0.44 ), the membership score for 'influential Presidency' is set at 0.67 in transport cooperation. The reasoning behind this way of calculating Presidency influence is the following: when looking back to a Presidency and asking whether it exerted influence in a certain policy area, one will certainly answer 'yes' if there was at least one output on which the Presidency exerted influence, even if on ten other outputs it did not exert influence. We are aware of the fact that this reduces the possible variation on the outcome: lower degrees of influence in a policy area can be 'hidden' behind outputs where influence was higher. However, grouping the outputs in policy areas is necessary to make the data comparable with QCA. In addition, this approach best fits our definition of influence, that is, changing a policy from what it would have been in the absence of an action. In other words, if an actor can change one part of a policy, it is safe to say that this actor changed the policy. Tables $1-3$ provide information of the individual outputs for each policy area, so this information is not 'lost' for the reader.

\section{Summary of Influence of the Hungarian, Polish and Lithuanian Council Presidencies}

As noted supra, a detailed description of the data on the three Presidencies would not be feasible within the scope of this article. An elaborate overview of the data for each Presidency is available in the online country files (see Supplemental data 1-3 online). A summary of the data is provided here in three tables. Tables 1-3 show the EaP-related outputs, grouped in policy areas (i.e. 'cases' in this article) for the Hungarian, Polish and Lithuanian Presidencies. The left column shows the policy areas, including the number of instances where the Presidencies were influential and not influential. The two columns in the middle summarize the outputs where the Presidencies were and were not influential, including the degree of influence between brackets. The right column shows the general level of PI for each policy area.

Table 4 summarizes all data for the three Presidencies per policy area, including the membership scores for the country-specific, issue-specific and context-related conditions for influence and the information on Presidency influence. The information in this table is the basis for the QCA on necessary and/or sufficient conditions for the Presidency to influence. The policy areas are ranked from high to low influence. 
Policy area for cooperation with the EaP countries (number of instances influential; number of instances not influential)

Bilateral political relations $(1 ; 0)$

Defence $(0 ; 0)$

Education/research/youth $(0 ; 0)$

Energy $(1 ; 1)$

JHA $(1 ; 1)$

\section{Multilateral political and institutional} framework $(2 ; 1)$

Trade/economic relations $(2 ; 1)$

Transport $(1 ; 0)$
Table 1. Influence of the Hungarian Presidency

Influence level for the policy area

- Belarus: sanctions (0.56)

Outputs not influential

0.00

- External energy priorities (partly EaP- - Trans-Caspian gas pipeline: discussions related) (0.67)

0.67 (partly EaPrelated) on negotiation mandate for European Commission (partly EaP-related) (0.44)

- Belarus, visa facilitation and

- Customs cooperation: high-level seminar 0.56 readmission agreements: negotiation mandate for European Commission (0.56)

- Establishment of EUSDR (partly EaP- • EaP Summit (0.00) related) (0.67)

- Söderköping process: integration in platform $1(0.56)$

- Ukraine: negotiations on DCFTA (0.56) - EaP Business Forum (0.00)

- Moldova: extension of trade preferences (0.56)

- Moldova, Common Aviation Area negotiation mandate $(0.56)$

Notes: DCFTA, deep and comprehensive free trade area; EUSDR, EU strategy for the Danube region. 
Table 2. Influence of the Polish Presidency

Policy area for cooperation with

the EaP countries (number of

instances influential; number of

instances not influential)

Outputs influential

Influence level for

Bilateral political relations (1;0) • Ukraine, Association Agreement: common understanding about contents $(0.56)$

Defence $(0 ; 0)$

Education/research/youth $(0 ; 1)$

Energy $(2 ; 0)$

- Trans-Caspian gas pipeline: negotiation mandate for European Commission (partly EaP-related) (0.56)

- Council conclusions on external energy priorities (partly EaP-related) (0.56)

JHA $(3 ; 3)$

- Armenia, visa facilitation and readmission agreements: negotiation mandate for European Commission (0.78)

- Azerbaijan, visa facilitation and readmission agreements: negotiation mandate for European Commission (0.78)

- JHA Council conclusions (0.56)

Multilateral political and

- Establishment of European Endowment for Democracy institutional framework $(1 ; 2)$ (partly EaP-related) (0.89)

- Police training: Euro-East training programme $(0.00)$

- Education: ministerial conference $(0.00)$ the policy area

- Drug-related crime: expert meeting $(0.00)$

- Customs cooperation: highlevel seminar (0.00)

- CORLEAP inaugural meeting $(0.00)$

0.56 (partly EaPrelated)

- EaP Summit (0.44)

- EaP Business Forum (0.00)

- Moldova, DCFTA: negotiation mandate for European Commission (0.56)

- Georgia, DCFTA: negotiation mandate for European

- Economy: ministerial conference $(0.00)$ Commission (0.56)

Transport $(2 ; 0)$

- Ministerial conference of Transport Ministers (0.67)

ement: European Commission negotiation mandate (0.56)

Note: CORLEAP, conference of regional and local authorities for the Eastern partnership. 
Table 3. Influence of the Lithuanian Presidency

Policy area for cooperation with the

EaP countries (number of

instances influential; number of

instances not influential)

Outputs influential

Bilateral political relations $(0 ; 4)$

Defence $(1 ; 5)$

Education/research/youth $(2 ; 1)$

Energy $(1 ; 1)$
- High-level seminar on EU-EaP defence cooperation (0.56)

- Education, science and research conference (0.67)

- EaP Youth Forum (0.67)

- Council report on external energy priorities (partly EaP-related) (0.56)
Influence level for the policy area

- Armenia, Association Agreement: failure 0.00 to initial (0.00)

- Georgia, Association Agreement: initialling (0.00)

- Moldova, Association Agreement: initialling (0.00)

- Ukraine, Association Agreement: failure to sign (0.00)

- European Council Conclusions on defence (0.00)

- ESDC training course with EaP representatives $(0.00)$

- Informal EU Defence Ministers' meeting (0.00)

- Informal EU Security Policy Directors' meeting (0.00)

- Georgia, initialling of CSDP Framework Participation Agreement (0.00)

- Launch of Erasmus+ (0.00)

- Meeting of strategic group for international energy cooperation $(0.00)$ 
JHA $(4 ; 3)$

Multilateral political and institutional framework $(0 ; 4)$

Trade/economic relations $(1 ; 2)$

Transport $(1 ; 1)$
- JHA ministerial meeting (0.78)

- CEPOL annual Presidency conference with EaP representatives (0.67)

- Belarus, visa facilitation and readmission agreement: start of negotiations $(0.56)$

- Moldova, visa liberalization (0.56)

- Ukraine, DCFTA: provisional application (0.56)

- Ministerial meeting of Transport Ministers (0.89)
- Azerbaijan, visa facilitation agreement: signature $(0.00)$

- Customs cooperation: high-level seminar (0.00)

- European Judicial Network: plenary meeting (0.00)

- EaP Summit: invitations to countries instead of specific people $(0.00)$

- EaP Summit: results $(0.00)$

- CORLEAP annual meeting (0.00)

- EU-EaP Foreign Ministers' meeting (0.00)

- EaP Business Forum (0.00)

- Moldova: opening of market for wines (0.00)

- Ukraine: air services agreement (0.00)

Notes: CEPOL, European Police College; CSDP, Common Security and Defence Policy; ESDC, European Security and Defence College. 
Table 4. Summary of data for the Hungarian, Polish and Lithuanian Presidencies

\begin{tabular}{|c|c|c|c|c|c|c|c|c|c|c|}
\hline Case & prep & bru & reput & large & $\begin{array}{l}\text { stab. } \\
\text { dom }\end{array}$ & $\begin{array}{l}\text { fav. } \\
\text { ext }\end{array}$ & $\begin{array}{l}\text { econ. } \\
\text { prosp }\end{array}$ & $\begin{array}{l}\text { sal. } \\
\text { pres }\end{array}$ & $\begin{array}{l}\text { fav.pref/ } \\
\text { sal.oth }\end{array}$ & $\begin{array}{l}\text { Influential } \\
\text { Presidency }\end{array}$ \\
\hline PL-multilateral political and institutional framework & 1.00 & 0.33 & 1.00 & 1.00 & 0.67 & 0.33 & 0.00 & 1.00 & 0.33 & 0.89 \\
\hline LT-transport & 1.00 & 0.33 & 1.00 & 0.00 & 1.00 & 0.00 & 0.00 & 1.00 & 0.67 & 0.89 \\
\hline PL-JHA & 1.00 & 0.33 & 1.00 & 1.00 & 0.67 & 0.33 & 0.00 & 1.00 & 0.33 & 0.78 \\
\hline LT-JHA & 1.00 & 0.33 & 1.00 & 0.00 & 1.00 & 0.00 & 0.00 & 1.00 & 0.33 & 0.78 \\
\hline H-energy & 0.67 & 0.67 & 0.33 & 0.33 & 1.00 & 0.33 & 0.00 & 0.67 & 0.33 & 0.67 \\
\hline H-multilateral political and institutional framework & 0.67 & 0.67 & 0.33 & 0.33 & 1.00 & 0.33 & 0.00 & 1.00 & 0.33 & 0.67 \\
\hline LT-education/research/youth & 1.00 & 0.33 & 1.00 & 0.00 & 1.00 & 0.00 & 0.00 & 1.00 & 0.67 & 0.67 \\
\hline H-bilateral political relations & 0.67 & 0.67 & 0.33 & 0.33 & 1.00 & 0.33 & 0.00 & 0.67 & 0.33 & 0.56 \\
\hline H-JHA & 0.67 & 0.67 & 0.33 & 0.33 & 1.00 & 0.33 & 0.00 & 0.00 & 0.33 & 0.56 \\
\hline H-trade/economic relations & 0.67 & 0.67 & 0.33 & 0.33 & 1.00 & 0.33 & 0.00 & 1.00 & 0.67 & 0.56 \\
\hline H-transport & 0.67 & 0.67 & 0.33 & 0.33 & 1.00 & 0.33 & 0.00 & 0.00 & 0.67 & 0.56 \\
\hline PL-bilateral political relations & 1.00 & 0.33 & 1.00 & 1.00 & 0.67 & 0.33 & 0.00 & 1.00 & 0.33 & 0.56 \\
\hline PL-energy & 1.00 & 0.33 & 1.00 & 1.00 & 0.67 & 0.33 & 0.00 & 1.00 & 0.33 & 0.56 \\
\hline LT-defence & 1.00 & 0.33 & 1.00 & 0.00 & 1.00 & 0.00 & 0.00 & 1.00 & 0.33 & 0.56 \\
\hline LT-energy & 1.00 & 0.33 & 1.00 & 0.00 & 1.00 & 0.00 & 0.00 & 1.00 & 0.33 & 0.56 \\
\hline LT-trade/economic relations & 1.00 & 0.33 & 1.00 & 0.00 & 1.00 & 0.00 & 0.00 & 1.00 & 0.67 & 0.56 \\
\hline H-defence & 0.67 & 0.67 & 0.33 & 0.33 & 1.00 & 0.33 & 0.00 & 0.00 & 0.33 & 0.00 \\
\hline H-education/research/youth & 0.67 & 0.67 & 0.33 & 0.33 & 1.00 & 0.33 & 0.00 & 0.00 & 0.67 & 0.00 \\
\hline PL-defence & 1.00 & 0.33 & 1.00 & 1.00 & 0.67 & 0.33 & 0.00 & 0.00 & 0.33 & 0.00 \\
\hline PL-education/research/youth & 1.00 & 0.33 & 1.00 & 1.00 & 0.67 & 0.33 & 0.00 & 0.33 & 0.67 & 0.00 \\
\hline LT-bilateral political relations & 1.00 & 0.33 & 1.00 & 0.00 & 1.00 & 0.00 & 0.00 & 1.00 & 0.33 & 0.00 \\
\hline LT-multilateral political and institutional framework & 1.00 & 0.33 & 1.00 & 0.00 & 1.00 & 0.00 & 0.00 & 1.00 & 0.33 & 0.00 \\
\hline
\end{tabular}


A first observation based on Table 4 is that there is a lack of variation on four conditions. Membership scores for prep and stab.dom are all above the threshold of 0.50 , whereas scores for fav.ext and econ.prosp are below 0.50. In other words, the Presidencies were rather well prepared (Hungary) or well prepared (Poland, Lithuania) and the domestic political and administrative context was rather stable (Poland) or stable (Hungary, Lithuania). In addition, the external political context was rather unfavourable (Hungary, Poland) to unfavourable (Lithuania), and the membership score for economic prosperity was 0.00 for all Presidencies. These four conditions will be excluded from the analysis since they could lead to paradoxical conclusions with QCA (e.g. an unfavourable economic context is necessary for the Presidency to be influential and to be not influential). The conditions are treated as further scope conditions for this article: the conclusions apply to Presidencies of domestically stable countries that are generally well prepared. In addition, these data do not allow making statements about the impact of context-related conditions: the results apply to Presidencies taking place in an unfavourable external political context and in a period of economic crisis.

\section{QCA Results and Discussion}

\section{One Necessary Condition: No Influence Without Salience to the Presidency ${ }^{6}$}

Using a threshold of 0.90 , the analysis shows that one condition is necessary for a Presidency to exert influence: sal.pres (consistency $=0.903614$ ), an issue-specific condition. This means that the incumbent country cannot use its role to increase its overall influence in the EU. The Presidency position does not automatically result in higher influence in the EU. Only in highly salient policy areas, where officials of the incumbent country are prepared to put specific efforts, can the Presidency increase its influence on EU decision-making.

The fact that salience to the Presidency is necessary for the Presidency to exert influence is not so surprising, especially because we view influence as the result of a deliberate intervention. What is more striking is that salience to the Presidency is the only necessary condition. All other conditions we investigated, including all country-specific ones, are individually not necessary. In other words, if, except salience to the Presidency, any of the conditions under consideration is absent, the Presidency can still exert influence if some other conditions are fulfilled. Small State Presidencies, countries with a bad reputation, or Member States who organize their Presidency in a capital-based way, can still exert influence if some other conditions are fulfilled. Presidency influence is also sometimes possible in policy areas where the distribution of preferences and salience among other actors is unfavourable.

\section{Sufficient Conditions: Causal Combinations Enabling Presidency Influence ${ }^{7}$}

The analysis of sufficient conditions is based on a truth table, summarizing all causal paths leading and not leading to Presidency influence (see Table 5).

Based on the data in this truth table, we define a consistency threshold of 0.80: there is a clear gap between the fifth and sixth causal paths (consistency $=0.845381$ and 0.724382 , respectively). In what follows, we summarize the results of the analysis with fsQCA. In the fsQCA software, membership in a set (condition) is expressed by the abbreviation of this condition (e.g. large country = 'large'), non-membership is expressed by the abbreviation 
Table 5. Truth table for 'influential Presidency'

\begin{tabular}{lccccccc}
\hline bru & reput & large & sal.pres & fav.pref/sal.ot & Number of cases & Influential pre & Consistency \\
\hline 1 & 0 & 0 & 1 & 0 & 3 & 0.952991 \\
1 & 0 & 0 & 1 & 1 & 1 & 0.933735 \\
0 & 1 & 1 & 1 & 1 & 2 & 0.897912 \\
0 & 1 & 1 & 1 & 0 & 4 & 0.889780 \\
0 & 1 & 0 & 1 & 1 & 3 & 0.845381 \\
0 & 1 & 0 & 1 & 0 & 5 & 0.724382 \\
1 & 0 & 0 & 0 & 1 & 2 & 0.582707 \\
1 & 0 & 0 & 0 & 0 & 2 & 0.582707 \\
0 & 1 & 1 & 0 & 1 & 1 & 0.442953 \\
0 & 1 & 1 & 0 & 0 & 1 & 0.442953 \\
\hline
\end{tabular}

preceded by ' $\sim$ ' (e.g. small country $=$ ' $\sim$ large'). The logical AND is shown as '*', the logical OR as ' + '.

The truth table analysis produces three solution terms that lead to 'influential Presidency' and indicates which cases correspond to these solution terms:

- sal.pres*bru* $\sim$ reput* large (consistency $=0.917910$ ). Cases with greater than 0.5 membership in this solution term: H-Energy, H-Multilateral political and institutional framework, H-Bilateral political relations, H-Trade and economic relations.

- $\quad$ sal.pres* $\sim$ bru*reput*large (consistency $=0.883598$ ). Cases with greater than 0.5 membership in this solution term: PL-JHA, PL-multilateral political and institutional framework, PL-transport, PL-bilateral political relations, PL-energy, PL-trade and economic relations.

- $\quad$ sal.pres $* \sim$ bru*reput*fav.pref/sal.ot (consistency $=0.848181$ ). Cases with greater than 0.5 membership in this solution term: LT-transport, LT-education/research/youth, LT-trade and economic relations, PL-transport, PL-trade and economic relations.

The first solution term (sal.pres*bru* $\sim$ reput* large), applying to outputs in EaP policies during the Hungarian Presidency, can be interpreted as follows: the incumbent country can be influential in areas that are highly salient to its Government, even if it does not have a good reputation. The fact that much of the Hungarian Presidency was Brussels-based may explain this: all interviewees agreed that the civil servants working for the Hungarian Presidency, especially those at the permrep, were highly competent and respected. Apparently, the country's rather small size did not prevent its officials from exerting influence in some dossiers. Hungarian interviewees noted that their country's size even had its advantages: bureaucratic chains were short, which allowed quick consultation and decision-making (Interview 1, $2,4,5)$. It is interesting to observe that the distribution of preferences and salience among the other actors does not seem to play an important role here. However, it must be noted that some crucial outputs in policy areas where this distribution was unfavourable - namely external energy policy priorities and the establishment of a strategy for the Danube Region - were only partly related to the EaP (see Supplemental data 1 online).

The second solution term (sal.pres* $\sim$ bru*reput*large) includes a number of EaP-related outputs during the Polish Presidency. It means that the Presidency can also be influential on highly salient issues that are mainly managed from the capital. Additional conditions are 
that the country should have a good reputation and be large. In other words, a large country with a good reputation can afford not to base its Presidency in Brussels, without decreasing its capacity to exert influence. Also for this group of cases, we can see that 'favourable distribution of preferences and salience among the other actors' is not part of the solution term; it covers cases where preferences and salience were distributed rather favourably (transport, trade and economic relations) as well cases where this was not the case (JHA, bilateral relations, the multilateral framework and energy - keeping in mind that the outputs in the latter policy areas were also only partly related to the EaP). In other words, it does not matter whether preferences and salience are favourably or unfavourably distributed in this solution term.

The third solution term (sal.pres* $\sim$ bru*reput*fav.pref/sal.ot) includes several EaPrelated policy developments during the Polish and the Lithuanian Presidencies. It shows that there is another sufficient combination of conditions under which Presidencies can influence highly salient policies that are mainly managed from the capital. Countries with a good reputation can exert influence in policy areas on which there is a (rather) favourable distribution of preferences and salience among the EU institutions and the other Member States. Indeed, this solution term covers only instances of Polish and Lithuanian influence in politically less sensitive policy areas: transport, education/research/youth, and trade and economic relations.

Given that the second and third solution terms are very similar, they can be merged into one solution term: sal.pres* $\sim$ bru*reput*(large+fav.pref/sal.ot). Bluntly stated, 'large country' and 'favourable distribution of preferences and salience among the other actors' are replaceable conditions in this solution term.

\section{Conclusion}

The systematic comparison of the influence of the Hungarian, Polish and Lithuanian Presidencies on the EU's EaP policies allows us to draw a number of general conclusions on necessity and sufficiency: most conditions for influence that were identified in the literature do not always need to be present (necessity), and individually they do not lead to influence (sufficiency). With QCA, we singled out the (combinations of) conditions that did and did not contribute to the influence of the respective Presidencies.

Only one individual condition is necessary, that is, salience to the Presidency. Furthermore, Presidency influence is also possible if some of the other conditions are absent. Apparently, a Presidency can be influential if it has a rather bad reputation (cf. Hungary) or if the distribution of preferences and salience among the other actors is unfavourable (cf. some cases of Hungary and Poland). Being large or small as such is not necessary for exerting influence either, and an influential Presidency is not always Brussels-based (cf. some cases of Poland and Lithuania).

An important observation on sufficiency is that all conditions we investigated appear in one or more of the three solution terms, but they do never have to be all present or absent in order to enable Presidency influence. For the Hungarian Presidency, its Brussels-based organization of EaP policies seems to be an important explanatory factor that compensated for the rather bad reputation of the country: EaP-related dossiers were mainly dealt with by Brussels-based officials who were largely praised for the way they organized the Presidency. Poland benefited in some policy areas from its good reputation and its capacities as a large State. In other, less sensitive policy areas, Poland and Lithuania took advantage of their good reputation and of the fact that the distribution of preferences and salience 
among other actors was rather favourable. In the second and third solution terms - which include 'high salience to the Presidency', 'not Brussels-based' and 'good reputation' - the conditions 'large country' and 'favourable distribution of preferences and salience among other actors' are mutually interchangeable. In other words, where the distribution of salience and preferences was rather unfavourable, Poland had an advantage (large State) that Lithuania did not have. We can conclude that the contribution of each of the conditions for influence depends on the presence of other conditions, and some conditions can become redundant in some causal paths.

The application of QCA is thus far unique to the study of influence of Council Presidency. It contributes to the opening up of the debate on the circumstances under which Presidencies can exert influence. The calibration of influence and the conditions for influence requires maximum transparency on the meaning of concepts, which also benefits the conceptual basis on which influence is researched.

It must be noted that, even though the analyses in this article are based on as many data as possible, the empirical basis is limited for two reasons. First, we encountered several conditions - preparation, domestic political and administrative context, political context and economic context - on which there was not enough variation to draw meaningful conclusions. The applicability of the research results is thus limited to (relatively) well-prepared Presidencies of Member States that are characterized by a (relatively) stable political and administrative context, taking place in an unfavourable political and economic environment. Second, the role of certain combinations of conditions could not be analysed because they were not represented in the cases. For example, what would be the influence of non-Brussels-based Presidencies with a bad reputation, or Brussels-based Presidencies with a good reputation? Would a large and Brussels-based Presidency have more influence than a small and Brussels-based Presidency?

To sum up, with QCA, we were able to single out (combinations of) conditions that did and did not play a role for the Presidencies in this study, allowing us to reflect on complex causal processes underlying Presidency influence. However, based on these results, we cannot draw up a model that would be applicable to all Presidencies; the results from QCA only allow for modest generalization (see, e.g. Berg-Schlosser et al., 2009), that is, they should be applicable to other cases if they share a reasonable number of scope conditions. Future research, focusing Presidencies to which the conditions for influence apply in more diverse ways, could further fine-tune and develop the insights that can be drawn from this analysis.

\section{Acknowledgements}

The authors would like to thank Hendrik Vos and Karolina Pomorska for their useful and constructive comments on earlier versions of this article.

\section{Funding}

This work was supported by the Research Foundation Flanders (FWO).

\section{Disclosure statement}

No potential conflict of interest was reported by the authors. 


\section{Supplemental data}

Supplemental data for this article can be accessed at http://dx.doi.org/10.1080/23745118.2015.1039248

\section{Notes}

1 The EaP, part of the European Neighbourhood Policy, is a framework for multilateral and bilateral cooperation between the EU and its Eastern neighbours: Belarus (participating only in the multilateral track), Ukraine, Moldova, Georgia, Armenia and Azerbaijan.

2 A detailed discussion of soft vs. hard knowledge is provided in the appendix.

3 Two other conditions related to policy areas and specific issues will not be discussed: the voting method (Elgström, 2006; Tallberg, 2006a; Warntjen, 2007; Bunse, 2009) and the stage in the decision-making process (Bjurulf \& Elgström, 2004; Tallberg, 2006b; Schalk et al., 2007; Thomson, 2008; Warntjen, 2008). These conditions have been studied in relation to EU legislation, but they are less applicable to - mostly non-legislative EaP policies.

4 It should be noted that some issues may be included for other reasons than salience (legal obligations, input from other Member States or the EU institutions, nearly finalized dossiers that the Presidency wishes to close in order to claim credit), or underemphasized in order not to be viewed as biased or because little progress on the issue is expected.

5 In the analysis, only the policy areas in which at least one of the Presidencies was influential will be considered. As a consequence, cooperation with the $\mathrm{EaP}$ on issues like agriculture support for civil society cooperation is not included in the analysis. None of the Presidencies exerted influence in these areas, despite some events taking place during the different semesters. Also, outputs where Presidency influence is theoretically impossible will not be considered. Examples of such outputs are those where the incumbent country is not involved as a host, organizer or chair (e.g. activities of other EU institutions), or if PI of any actor is impossible (e.g. Cooperation Council meetings, who take stock of bilateral relations but do not decide on policy).

6 A condition is necessary if it is a superset of the outcome, that is, if the condition must be present for the outcome to occur. For a necessary condition, its membership score is consistently higher than or equal to the membership score in the outcome. The formula for necessity of condition $X$ for outcome $Y$ is $\sum_{\min }\left(X_{i}, Y_{i}\right) / \sum\left(Y_{i}\right)$. 'min' refers to the selection of the lower of the two values $X_{i}$ or $Y_{i}$.

7 Conditions are sufficient for the outcome if they are a subset of the outcome, that is, if the outcome is present as soon as the conditions are present. A combination of conditions is considered sufficient if the membership scores in causal paths are consistently lower than or equal to the membership scores of these cases in the outcome. The formula for sufficiency of causal path $X$ for outcome $Y$ is $\sum_{\min }\left(X_{i}, Y_{i}\right)$ / $\sum\left(X_{i}\right)$

8 Along with some 'traditional' ways of operationalizing size (see infra), other operationalizations have been proposed in the literature as well (Thorhallsson \& Wivel, 2006; Drulák \& Šabič, 2010; Buchet de Neuilly, 2011). Since these overlap with other conditions for Presidency influence, these operationalizations are not applied in this article.

9 The ranking of Member States according to size based on population, voting weight, the Shapley Shubik Index (Bolus, 2010) or the Banzhaf Index (Bailer, 2006) are nearly identical.

\section{List of Interviews}

Interview 1. Hungarian Permanent Representation to the EU, Brussels, 29 February 2012. Interview 2. Hungarian Permanent Representation to the EU, Brussels, 6 March 2012. Interview 3. EEAS, Brussels, 18 April 2012.

Interview 4. Hungarian Ministry of Foreign Affairs, Budapest, 8 May 2012.

Interview 5. Hungarian Ministry of Foreign Affairs, Budapest, 10 May 2012.

Interview 6. European Commission, Brussels, 16 October 2012.

Interview 7. European Commission, Brussels, 24 October 2012.

Interview 8. European Commission, Brussels, 7 November 2012. 
Interview 9. European Commission, Brussels, 21 November 2012.

Interview 10. Diplomat from EU country, Vilnius, 19 March 2013.

Interview 11. Lithuanian Permanent Representation to the EU, Brussels, 19 June 2013.

Interview 12. Diplomat from EU country, Brussels, 7 July 2014.

\section{References}

Arter, D. (2000) Small state influence within the EU: The case of Finland's 'northern dimension initiative', Journal of Common Market Studies, 38(5), pp. 677-697.

Arts, B. \& Verschuren, P. (1999) Assessing political influence in complex decision-making: An instrument based on triangulation, International Political Science Review, 20(4), pp. 411-424.

Bailer, S. (2006) The dimensions of power in the European Union, Comparative European Politics, 4(4), pp. 355-378.

Baillie, S. (1998) A theory of small state influence in the European Union, Journal of Development and International Cooperation, 1(3-4), pp. 195-219.

Baun, M. (2009, April) Czech Foreign Policy and EU Membership: Europeanization and domestic sources. Paper presented at the eleventh biennial conference of the European Studies Association, Los Angeles, CA.

Bengtsson, R. (2002) Soft security and the presidency, Cooperation and Conflict, 37(2), pp. 212-218.

Berg-Schlosser, D., De Meur, G., Rihoux, B., \& Ragin, C. C. (2009) Qualitative Comparative Analysis (QCA) as an approach, in: D. Berg-Schlosser \& G. De Meur (Eds) Configurational Comparative Methods: Qualitative Comparative Analysis (QCA) and related techniques, pp. 1-18 (Thousand Oaks, CA: Sage Publications).

Björkdahl, A. (2008) Norm advocacy: A small state strategy to influence the EU, Journal of European Public Policy, 15(1), pp. 135-154.

Bjurulf, B. (2001) How Did Sweden Manage the European Union? ZEI Discussion Papers, C 96.

Bjurulf, B. \& Elgström, O. (2004) Negotiating transparency: The role of institutions, Journal of Common Market Studies, 42(2), pp. 249-269.

Bolus, S. (2010) Power Index Calculator. Available at http://korsika.informatik.uni-kiel.de/ stb/power_indices/ index.php (accessed 2 October 2011).

Buchet de Neuilly, Y. (2011) Sous l'emprise de la présidence: Déplacements structurels, construction des intérêts et stratégies des diplomates au Conseil, Politique européenne, 35(3), pp. 83-113.

Bunse, S. (2009) Small States and EU Governance: Leadership through the Council Presidency (New York, NY: Palgrave Macmillan).

Bursens, P. \& Van Hecke, S. (2011) Caretaker at home, successful administrator in Europe, in: S. Van Hecke \& P. Bursens (Eds) Readjusting the Council Presidency: Belgian leadership in the EU, pp. 245-268 (Brussel: ASP).

Charléty, V. \& Mangenot, M. (Eds.) (2011) Le système présidentiel de l'Union européenne après Lisbonne (Strasbourg: École nationale d'administration).

Copsey, N. \& Pomorska, K. (2010) Poland's power and influence in the EU: The case of its Eastern policy, Comparative European Politics, 8(3), pp. 304-326.

Craig, P. (2011) The Lisbon Treaty. Law, politics, and treaty reform (Oxford: Oxford University Press).

Crespy, A. \& Verschueren, N. (2009) From Euroscepticism to resistance to European integration: An interdisciplinary perspective, Perspectives on European Politics and Society, 10(3), pp. 377-393.

Culley, P., Neisse, J., \& Raik, E. (2011) Le trio de présidences, in: V. Charléty \& M. Mangenot (Eds) Le système présidentiel de l'Union européenne après Lisbonne, pp. 79-91 (Strasbourg: École nationale d'administration).

Dewost, J.-L. (1984) La Présidence dans le cadre institutionnel des Communautés Européennes, Revue du Marché Commun, 27(273), pp. 31-34.

Dijkstra, H. (2011) EU External Representation in Conflict Resolution: When does the Presidency or the high representative speak for Europe? European integration online papers, 15 (Article 1). Available at http://eiop. or.at/eiop/texte/2011-001a.htm (accessed 30 November 2014).

Drulák, P. \& Šabič, Z. (2010) Analysis: Czech trouble-makers and Slovenian role models, in: P. Drulák \& Z. Šabič (Eds) The Czech and Slovenian EU Presidencies in a Comparative Perspective, pp. 281-290 (Dordrecht: Republic of Letters).

Elgström, O. (2006) The presidency: The role(s) of the chair in European Union negotiations, The Hague Journal of Diplomacy, 1(2), pp. 171-195. 
Fernández Pasarín, A. M. (2009) La présidence du Conseil de l’UE: du pouvoir de la responsabilité à la responsabilité du pouvoir. Available at http://www.etudes-europeennes.eu/les-presidences-tournantes-duconseil-de-lue/la-presidence-du-conseil-de-lue-du-pouvoir-de-la-responsabilite-a-la-responsabilite-du-pouvoir. html (accessed 1 March 2012).

Hayes-Renshaw, F. \& Wallace, H. (2006) The Council of Ministers (London: Palgrave Macmillan).

Jakobsen, P. V. (2009) Small states, big influence: The overlooked nordic influence on the civilian ESDP, Journal of Common Market Studies, 47(1), pp. 81-102.

Kajnč, S. (2009) Channels of Cooperation: A case study of Slovenia's Presidency of the EU, EPIN Working Paper (21).

Kajnč, S. \& Svetličič, M. (2010) What it takes to run an EU Presidency: Study of competences in Slovenia's public administration, Halduskultuur - Administrative Culture, 11(1), pp. 84-109.

Karoliewski, I. P. \& Sus, M. (2011) The Polish EU Council Presidency (Warsaw: Friedrich Erbert Stiftung Perspective).

Langdal, F. \& von Sydow, G. (2009) The 2009 Swedish EU Presidency: The setting, priorities and roles (Stockholm: Swedish Institute for European Policy Studies).

Leconte, C. (2012) Eurosceptics in the rotating presidency's chair: Too much ado about nothing? Journal of European Integration, 34(2), pp. 133-149.

Ludlow, P. (1993) The UK presidency: A view from Brussels, Journal of Common Market Studies, 31(2), pp. 246-260.

Metcalfe, D. (1998) Leadership in European Union negotiations: The presidency of the council, International Negotiation, 3(3), pp. 413-434.

Pintelon, O. \& Van Lancker, W. (2011) Weinig speelruimte, onmiskenbare invloed: Het Belgisch EUVoorzitterschap en de Europese sociale agenda, Res Publica, 53(3), pp. 315-335.

Quaglia, L. \& Moxon-Browne, E. (2006) What makes a good EU presidency? Italy and Ireland compared, Journal of Common Market Studies, 44(2), pp. 349-368.

Rihoux, B. \& Ragin, C. C. (Eds.) (2009) Configurational Comparative Methods: Qualitative Comparative Analysis (QCA) and related techniques (Thousand Oaks, CA: Sage publications).

Schalk, J., Torenvlied, R., Weesie, J., \& Stokman, F. N. (2007) The power of the presidency in EU council decision-making, European Union Politics, 8(2), pp. 229-250.

Schneider, C. Q. \& Wagemann, C. (2012) Set-Theoretic Methods for the Social Sciences. A guide to qualitative comparative analysis (New York, NY: Cambridge University Press).

Tallberg, J. (2003) The agenda-shaping powers of the Council Presidency, in: O. Elgström (Ed) European Union Council Presidencies: A comparative perspective, pp. 18-37 (London: Routledge).

Tallberg, J. (2004) The power of the presidency: Brokerage, efficiency and distribution in EU negotiations, Journal of Common Market Studies, 42(5), pp. 999-1022.

Tallberg, J. (2006a) Formal leadership in multilateral negotiations: A rational institutionalist theory, The Hague Journal of Diplomacy, 1(2), pp. 117-141.

Tallberg, J. (2006b) Leadership and Negotiation in the European Union (Cambridge: Cambridge University Press).

Tallberg, J. (2008) Bargaining power in the European council, Journal of Common Market Studies, 46(3), pp. $685-708$.

Thomson, R. (2008) The council presidency in the EU: Responsibility with power, Journal of Common Market Studies, 46(3), pp. 593-617.

Thomson, R. \& Stokman, F. N. (2006) Research design: Measuring actors' positions, saliences and capabilities, in: R. Thomson, F. N. Stokman, C. H. Achen, \& T. König (Eds) The European Union Decides, pp. 25-53 (Cambridge: Cambridge University Press).

Thorhallsson, B. \& Wivel, A. (2006) Small states in the EU: What do we know and what would we like to know? Cambridge Review of International Affairs, 19(4), pp. 651-668.

Tulmets, E. (2011) Introduction: Identity and solidarity in the Foreign Policy of East Central European EU Members: Renewing the research agenda, Perspectives, 19 (2, Special Issue, Identity and Solidarity in Foreign Policy: Investigating East Central European relations with the Eastern Neighbourhood), pp. 5-26.

Vaïsse, J., Dennison, S., \& Kundnani, H. (Eds.) (2013) European Foreign Policy Scorecard 2013 (London: European Council on Foreign Relations (ECFR)).

Van Hecke, S. \& Bursens, P. (Eds.) (2011) Readjusting the Council Presidency: Belgian leadership in the EU. (Brussel: ASP). 
Vandecasteele, B. (2014) Influence of the Lithuanian Presidency of the EU Council on EU relations with countries of the Eastern partnership, Lithuanian Foreign Policy Review, 17(31), pp. 37-66.

Vandecasteele, B. \& Bossuyt, F. (2014) Assessing EU council presidencies: (Conditions for) success and influence, Comparative European Politics, 12(2), pp. 233-247.

Vandecasteele, B., Bossuyt, F., \& Orbie, J. (2013) Unpacking the Influence of the Council Presidency on European Union External Policies: The Polish Council Presidency and the Eastern Partnership, European Integration online papers, 17 (Special Issue 1: Agency and influence inside the EU institutions), pp. 1-28.

Vanhoonacker, S., Pomorska, K., \& Maurer, H. (2010) The Council Presidency and European Foreign Policy; Challenges for Poland in 2011 (Maastricht: Center for International Relations).

Vanhoonacker, S., Pomorska, K., \& Maurer, H. (2011) The presidency in EU external relations: Who is at the helm? Politique européenne, 35(3), pp. 139-164.

Vida, K. (2010) Introduction: A theoretical approach, in: K. Vida (Ed) The Impact of the 10 New Member States on EU Decision-Making: The experience of the first years, pp. 4-11 (Budapest: Foundation for European Progressive Studies).

Vos, H. \& Bailleul, E. (2002) The Belgian Presidency and the Post-Nice Process After Laeken, ZEI Discussion Paper, C 102.

Warntjen, A. (2007) Steering the Union: The impact of the EU presidency on the legislative activity in the council, Journal of Common Market Studies, 45(5), pp. 1135-1157.

Warntjen, A. (2008) The council presidency: Power broker or burden? An empirical analysis, European Union Politics, 9(3), pp. 315-338.

Warntjen, A. (2013a) The elusive goal of continuity? Legislative decision-making and the council presidency before and after Lisbon, West European Politics, 36(6), pp. 1239-1255.

Warntjen, A. (2013b) Overcoming gridlock: The council presidency, legislative activity and issue de-coupling in the area of occupational health and safety regulation, Journal of Contemporary European Research, 9(1), pp. 39-59.

\section{Appendix. Defining and operationalizing (conditions for) Presidency influence}

\section{The Outcome: An Influential Presidency}

The definition of 'influential Presidency' - the outcome to be analysed across the cases - and the method for measuring influence are based on an approach that was used in other studies on Presidency influence (Vandecasteele et al., 2013; Vandecasteele, 2014). Exerting PI is understood as intentionally changing a policy from what it would have been in the absence of an action. The degree of PI is established for every EaP-related output during the respective Presidencies, according to a method that was initially developed by Arts and Verschuren (1999). PI is a function of three indicators: the degree of goal achievement (GA), the extent to which GA can be ascribed to the presidency (AS) and the political relevance (PR) of the output. Table A1 shows how GA, AS and PR are operationalized. PI is calculated in two steps. First, a number between 0 and 3 is assigned to GA, AS and PR: $0=$ none, $1=$ limited, 2 = substantial, 3 = high. Second, the degree of PI is expressed as the average of GA, AS and PR: the scores of the three indicators are summed up and divided by 9 , which results in a score between 0 and 1 . Thus, the formula for calculating PI is $(\mathrm{GA}+\mathrm{AS}+\mathrm{PR}) / 9$, resulting in ten possible values: $0,0.11,0.22,0.33,0.44,0.56$, $0.67,0.78,0.89$ and 1 . The PI scores can be reformulated in verbal categories. All scores below 0.50 equate to 'no influence' since they are below the 0.5 threshold; 0.56 indicates 'limited influence'; 0.67 and 0.78 show 'substantial influence'; and 0.89 and 1 are expressions of 'high influence'. The formula for PI is further specified on two points. First, a score of 0 for GA, AS or PR automatically results in PI = 0: if an actor did not achieve its goals, the output cannot be ascribed to the actor, or the output was politically irrelevant, it would be unjustified to claim that this actor influenced a policy. Consequently, PI scores of 0.11 and 0.22 do not occur in practice. Second, AS is assigned particular weight in the formula, given that this represents a key element of our definition of influence. The level of PI cannot be higher than the level of AS: if AS is limited (a score of 1), PI cannot be higher than limited (0.56); if AS is substantial (a score of 2), PI cannot be higher than substantial (0.78).

The method for establishing the influence of the Presidency differs from the one that was used in other studies (Warntjen, 2008 and Schalk et al., 2007 look at the distance between the Presidency's preferred outcome and the actual outcome, compared to what can be expected on the basis of the country characteristics). We believe that the method based on the work of Arts and Verschuren (1999) most accurately captures the different aspects of influence in a policy area, notably by including a measurement for political relevance. 
Table A1. Operationalization of Presidency influence

\begin{tabular}{|c|c|c|}
\hline Indicator & Level & Description \\
\hline \multirow[t]{4}{*}{ Goal achievement (GA) } & 0 & The output entirely contradicts the Presidency's preferences \\
\hline & 1 & The output partly contradicts the Presidency's preferences \\
\hline & 2 & $\begin{array}{l}\text { The output does not contradict the Presidency's preferences, } \\
\text { but is not its most preferred result }\end{array}$ \\
\hline & 3 & $\begin{array}{l}\text { The output reflects the Presidency's preferences as much as was } \\
\text { legally and practically feasible }\end{array}$ \\
\hline \multirow[t]{4}{*}{$\begin{array}{l}\text { Ascription of goal } \\
\text { achievement (AS) }\end{array}$} & 0 & $\begin{array}{l}\text { The Presidency was not involved as a chair (in this case, the } \\
\text { output is irrelevant for the analysis), or was involved as a } \\
\text { chair but had no role in developing the output }\end{array}$ \\
\hline & 1 & $\begin{array}{l}\text { The Presidency was involved as a chair to a limited extent, but } \\
\text { the output was mainly developed by other actors }\end{array}$ \\
\hline & 2 & $\begin{array}{l}\text { The Presidency was involved as a chair and steered the output, } \\
\text { but other actors also played a major role in developing the } \\
\text { output }\end{array}$ \\
\hline & 3 & $\begin{array}{l}\text { The Presidency was involved as a chair and it is unlikely that } \\
\text { the output would have been the same if another country held } \\
\text { the Presidency }\end{array}$ \\
\hline \multirow[t]{4}{*}{ Political relevance (PR) } & 0 & $\begin{array}{l}\text { The output is of little or no political importance, is not novel } \\
\text { among EU policies and is not tangible }\end{array}$ \\
\hline & 1 & $\begin{array}{l}\text { The output is politically important or novel among EU policies, } \\
\text { but is not tangible }\end{array}$ \\
\hline & 2 & $\begin{array}{l}\text { The output is tangible, but of limited political importance and } \\
\text { novelty among EU policies }\end{array}$ \\
\hline & 3 & $\begin{array}{l}\text { The output is tangible and politically important or novel among } \\
\text { EU policies }\end{array}$ \\
\hline
\end{tabular}

\section{The Conditions for Influence}

In calibrating set membership for the conditions for influence, we define four possible scores: absent/non-member (0.00), rather absent/more out than in (0.33), rather present/more in than out (0.67) and present/full member (1.00). The operationalization of these conditions for influence is provided in the following paragraphs and summarized in Table A2.

For 'adequate preparation', $0.00=$ none of the following: clear formulation of priorities, adequate staff training, efficient general planning; $0.33=$ one of the aforementioned; $0.67=$ two of the aforementioned; $1.00=$ all components of adequate preparation.

'Brussels-based Presidency' is operationalized as follows: $0.00=$ none of the following: priorities are developed jointly by the permrep and the capital, the permrep staff has relative autonomy vis-à-vis the capital in formulating compromise proposals and most chairs of working parties that meet regularly reside in Brussels; 0.33 $=$ one of the aforementioned; $0.67=$ two of the aforementioned; $1.00=$ all components of a Brussels-based Presidency.

The reputation of a Member State's officials can of course differ between individual chairpersons. In this article, we capture the reputation in one number. As discussed supra, reputation depends on whether the Member State is considered to give the 'right example' in domestic policies, whether the political leadership of a country has a positive attitude towards European integration, and whether it invests in the soft knowledge of its chairpersons. This third dimension, soft knowledge, is a type of 'expertise'. We follow the argument of Kajnč and Svetličič (2010) that 'expertise' refers to both hard and soft knowledge. Since these types of knowledge do not necessarily coincide, we avoid using the term 'expertise' in the article. Hard knowledge is knowledge on 'why' and 'what' questions: dossiers, procedures, facts, history. The level of hard knowledge among civil servants usually corresponds to the degree of interest of a country's leadership in a certain topic, and will therefore not be 
Table A2. Operationalization of conditions for influence

\section{Condition
Country-}

specific preparation

Brussels-based

Presidency

Good reputation

Large country

Stable domestic political and administrative context

Absent (0.00)

None of the following: clear formulation of priorities, adequate staff training, efficient planning

None of the following: priorities are developed jointly by the permrep and the capital, the permrep staff has relative autonomy vis-à-vis the capital in formulating compromise proposals, and most chairs of working parties that meet regularly reside in Brussels

Rather absent (0.33)

One of the following: clear formulation of priorities, adequate staff training, efficient planning

One of the following: priorities are developed jointly by the permrep and the capital, the permrep staff has relative autonomy vis-à-vis the capital in formulating compromise proposals, most chairs of working parties that meet regularly reside in Brussels Rather present (0.67) Present (1.00)

Two of the following: clear formulation of priorities, adequate staff training, efficient planning

Two of the following: priorities are developed jointly by the permrep and the capital, the permrep staff has relative autonomy vis-à-vis the capital in formulating compromise proposals, most chairs of working parties that meet regularly reside in Brussels

Two of the following: 'right example' at home, positive attitude to European integration, Presidency invests in soft knowledge of

chairpersons
Between the average and

example' at home, positive attitude to European integration, Presidency attitude to European integration, Presidency invests in soft knowledge of chairpersons invests in soft knowledge of chairpersons (less than 9 million)

None of the following: efficient coordination between and within State services, strong support for the Government, no national or important regional elections during Presidency period
Between half the average and less than 18 million) twice the average (from 18 to 36 million)

One of the following: efficient Two of the following: coordination between and within State services, strong support for the Government, no national or important regional elections during Presidency period efficient coordination between and within State services, strong support for the Government, no national or important regional elections during Presidency period
Clear formulation of priorities, adequate staff training, and efficient planning

Priorities are developed jointly by the permrep and the capital, the permrep staff has relative autonomy vis-à-vis the capital in formulating compromise proposals, and most chairs of working parties that meet regularly reside in Brussels

'Right example' at home, positive attitude to

European integration and Presidency invests in soft knowledge of chairpersons

More than twice the average (more than 36 million)

Efficient coordination between and within State services, strong support for the Government, no national or important regional elections during Presidency period 
Issue- High salience to the The issue is not explicitly specific Presidency

Favourable distribution of preferences and salience among other actors

External Favourable external None of the following: a political context

\section{Economic} prosperity mentioned in the

Presidency programme, and interviewees and secondary sources reveal that the issue is not important to the Presidency

The issue is explicitly

The other actors hold

One of the following: a and absence of unexpected events or crises

Economic growth of up to 0.5 decline in at least one EU Member State and a general climate of economic crisis mentioned in the

Presidency programme, but interviewees and secondary sources reveal that the issue is not important to the Presidency heterogeneous positions and the policy area is highly salient to them positive political climate regarding the topics of interest to the Presidency, absence of domestic events in EU countries or global developments that divert attention from the topics of interest to the Presidency, or absence of unexpected events or crises per cent in all EU Member

The issue is not explicitly

The other actors hold

Two of the following: a absence of domestic events States but a general climate of economic crisis mentioned in the

Presidency programme, but interviewees and secondary sources reveal that the issue is important to the Presidency heterogeneous positions and the policy area is of low salience to them positive political climate regarding the topics of interest to the Presidency, in EU countries or global developments that divert attention from the topics of interest to the Presidency, and/or absence of unexpected events or crise

The issue is explicitly mentioned in the

Presidency programme (except for unexpected events), and interviewees and secondary sources reveal that the issue is important to the Presidency

The other actors hold homogeneous positions, corresponding to the Presidency's preferences

A positive political climate regarding the topics of interest to the Presidency, absence of domestic events in EU countries or global developments that divert attention from the topics of interest to the Presidency, and absence of unexpected events or crises

conomic growth of up to 0.5 Economic growth of more per cent in all EU Member States and economic than 0.5 per cent in all EU Member States 


\section{B. Vandecasteele et al.}

discussed as part of the reputation of a country, but in conjunction with salience of policy areas (see infra). Soft knowledge, by contrast, concerns 'how' and 'who' questions and stimulates a constructive atmosphere. It is effective in a negative rather than a positive way: smooth management of negotiations does as such not yield positive results, but poor management gives rise to irritation and mistrust (Vanhoonacker et al., 2010). The latter aspect of soft knowledge - networking (including formal and informal coordination with other Member States and the EU institutions) - has been discussed by some authors (Bjurulf, 2001; Bunse, 2009; Kajnč, 2009; Karoliewski \& Sus, 2011), without explicitly linking this to the reputation of the incumbent. In this research, however, we do consider networking as part of soft knowledge and thus of reputation, since the skills for alliance building are similar to the other soft skills. In sum, 'good reputation' is operationalized as follows: $0.00=$ none of the following: 'right example' at home, the Government has a positive attitude to European integration, the Presidency invests in soft knowledge of chairpersons; $0.33=$ one of the aforementioned; $0.67=$ two of the aforementioned; $1.00=$ all components of a good reputation.

There are many ways ${ }^{8}$ of operationalizing the size of a country, which is also one of the conditions for Presidency influence. In this article, population is taken as the indicator of a Member State's size. 'Large country' is operationalized in relation to the average population of EU Member States (approximately 18/507 million): $0.00=$ less than half the average (less than 9 million), $0.33=$ more than 9 million and less than 18 million, $0.67=$ between the average and twice the average (from 18 to 36 million), $1.00=$ more than twice the average (more than 36 million).

The operationalization of 'stable domestic political and administrative context' is $0.00=$ none of the following: efficient coordination between and within State services, strong parliamentary support for the Government, no national or important regional elections during the Presidency period; $0.33=$ one of the aforementioned; $0.67=$ two of the aforementioned; $1.00=$ all components of a stable domestic political and administrative context.

As outlined supra, salience of a policy area to the Presidency is strongly related to hard knowledge. High salience generally motivates the development of a high level of hard knowledge of a country's civil servants and politicians, and vice versa (Schalk et al., 2007; Warntjen, 2007). In this article, salience therefore includes hard knowledge. 'High salience to the Presidency' is operationalized as follows: $0.00=$ the issue is not explicitly mentioned in the Presidency programme, and interviewees and secondary sources reveal that the issue is not important to the Presidency; $0.33=$ the issue is explicitly mentioned in the Presidency programme, but interviewees and secondary sources reveal that the issue is not important to the Presidency; $0.67=$ the issue is not explicitly mentioned in the Presidency programme, but interviewees and secondary sources reveal that the issue is important to the Presidency; $1.00=$ the issue is explicitly mentioned in the priority programme (for unexpected events this criterion is dropped), and interviewees and secondary sources reveal that the issue is important to the Presidency. Salience to the Presidency is grouped per policy area in the same way as PI per policy area: the maximum score of salience for all outputs in the policy area is taken as the membership score for the whole policy area. If, for example, one issue in the area of trade with the EaP countries is highly salient to the Presidency (1.00), salience of 'trade/economic relations' is scored as 1.00 too. Detailed information on operationalization of salience is provided in the online country files (see Supplemental data 1-3 online).

Our operationalization of salience to the Presidency differs from those that were put forward by other authors. In some studies (see, e.g. Thomson \& Stokman, 2006; Schalk et al., 2007), 'salience' is seen as the proportion of an actor's potential capabilities it is willing to mobilize in order to influence outcomes, or the extent to which actors experience utility loss from outcomes that differ from the one that it most favoured. The importance of an issue is measured here through expert judgements that provide a score on a scale of 0-100. Warntjen (2007), in turn, uses the election programmes of the parties in the Government as a proxy for salience, cross-validated with the Presidency programme as presented to the European Parliament. In our view, the operationalization of salience to the Presidency as we present it, is the most suitable to make the scores applicable in a QCA research design. For a score between 0 and 100, it would be difficult to establish a threshold when an issue is or is not salient. In addition, for EaP policies, it would not be sufficient to base the membership score (only) on party/Presidency programmes or expert judgements. In order to take strategic prioritization and salience of unexpected events into account, a combination of the two is necessary.

A 'favourable distribution of preferences and salience among other actors' is operationalized as follows: $0.00=$ the other actors (Member States, institutions) hold homogeneous positions, not corresponding to the Presidency's preferences; $0.33=$ the other actors hold heterogeneous positions and the policy area is highly salient to them; $0.67=$ the other actors hold heterogeneous positions and the policy area is of low salience to them; $1.00=$ the other actors hold homogeneous positions, corresponding to the Presidency's preferences. As explained supra, the points of view on the intensity, scope, underlying principles and finality of EU-EaP cooperation greatly diverge among Member States and EU institutions. Some view the EaP initiative as a 
stepping stone for further enlargement of the EU, while others consider it an alternative. Hungary, Poland and Lithuania belong to the former group. The EU institutions were generally supportive of the activities of these three Presidencies with regard to the EaP (Interview 10, 11): especially European Commission officials signalled that they see it as an advantage when 'their' policy areas are promoted at the political level (Interview $6,7,8,9)$.

For a 'favourable external political context', $0.00=$ none of the following: a positive political climate regarding the topics of interest to the Presidency, absence of domestic events in EU countries or global developments that divert attention from the topics of interest to the Presidency, and absence of unexpected events or crises; $0.33=$ one of the aforementioned; $0.67=$ two of the aforementioned; $1.00=$ all aforementioned components.

Economic prosperity can be hardly captured in one number. For reasons of simplicity and comparability, we use the growth rate and the general economic climate as proxies for 'economic prosperity' and thus operationalize this condition as follows: $0.00=$ economic stagnation or decline in at least one EU Member State and a general climate of economic crisis; $0.33=$ economic growth of up to 0.5 per cent in all EU Member States, but a general climate of economic crisis; $0.67=$ economic growth of up to 0.5 per cent in all EU Member States and economic optimism; $1.00=$ economic growth of more than 0.5 per cent in all EU Member States. 